\title{
Synthesis and characterization of 2- acetyl furan benzoyl hydrazone and its applications in the spectrophotometric determination of cu (ii)
}

\begin{abstract}
The new chromogenic reagent 2-acetylfuran benzoylhydrazone (AFBH) is synthesised, studied its characteristic properties and applied for the spectrophotometric determination of Copper (II) for the first time. The reagent gives greenish yellow complexes with copper (II) in sodium acetate-acetic acid buffer medium of $\mathrm{pH}$ 6.5. The molar absorptivities of copper complex is $2.05 \times 10^{4} \mathrm{Lmol}^{-1} \mathrm{~cm}^{-1}$. The colour reactions have been investigated for the micro spectrophotometric determination of copper (II) in aqueous medium and applied for various water and biological samples.
\end{abstract}

Keywords: benzoylhydrazone, spectrophotometric determination, copper (II), environment samples
Volume I Issue 3 - 2017

\section{$\checkmark$ Saleem Basha}

Department of Chemistry, Government College (Autonomous), India

Correspondence: $\vee$ Saleem Basha, Department of Chemistry, Government College (Autonomous), Anantapur, Andhra Pradesh, India, Email saleemchem08@gmail.com

Received: June 24, 2017 | Published: August 0I, 2017

\section{Introduction}

Copper is an important element in biological, industrial and environmental chemistry. Copper plays a key role in biological processes (e.g. Synthesis of haemoglobin, oxidases, enzymes, etc.). It is an important constituent of proteins and enzymes. It is essential for mammals in the synthesis of hemoglobin. Though copper is an essential element, it become hazardous when present in excess. Discharge of copper containing waste into environment leads to the natural imbalance of the ecosystem. Elevated level of copper in soil also affects the growth and metabolism of plants. ${ }^{1}$ The excessive accumulation of copper in liver, kidney, brain and cornea ${ }^{2}$ leads to failure of liver, mall function of kidney and various neurological abnormalities (Wilson's disease symptoms). For these reasons the analytical monitoring of copper in environmental, biological, industrial, and leafy vegetable and food samples is extremely important. Literature survey indicates that some extractive spectrophotometric method were reported for the determination of copper. ${ }^{3,4}$

This paper describes the non-extractive spectrphotometric determination of copper (II) as its AFBH complex in aqueous medium. A close literature survey reveals that AFBH has so far not been employed for the analytical determination of copper (II). This method does not require an extraction step, hence the use of carbon tetrachloride or chloroform as solvent is avoided which are reported as toxic and environmental pollutants and carcinogens. Compare to even some recently published spectrophotometric methods for the determination of copper (II), the present method here offers several distinct advantages.

\section{Experimental}

\section{Synthesis of AFBH}

2-acetylfuran $(2 \mathrm{ml}, 0.02 \mathrm{~mol})$ in $5 \mathrm{ml}$ of methanol, benzoylhydrazide $(2.7 \mathrm{~g}, 0.02 \mathrm{mo})$, dissolved in $10 \mathrm{ml}$ of hot water were mixed in a clean round bottom flask. Suitable quantity $(\sim 2 \mathrm{ml})$ of glacial acetic acid was added to the reaction mixture and refluxed with stirring for 5 hours. Pale yellow coloured product was separated out on cooling. It was collected by filtration, washed several times with hot water and 50 percent cold methanol and recrystalised from ethanol and dried in vacuum yield $2.5 \mathrm{gram}$, melting point $145148^{\circ} \mathrm{C}$.<smiles>CC(=O)c1ccco1</smiles>

AFBH

Figure I Synthesis of AFBH.

\section{Characterization of AFBH ${ }^{5}$}

The compound was chararacterized by IR, NMR, Mass and UV spectral analysis.

i. Infrared spectrum of AFBH: shows strong bands at 3228(s), 3117(m), 3031(m), 2950(m), 1653(s), 1605(m), 1590(s), 1571(m), $1526(\mathrm{~s}), 1483(\mathrm{~m}), 1280(\mathrm{~s}), \mathrm{cm}^{-1}$ respectively corresponding to $v(\mathrm{NH})$ secondary, $v(\mathrm{C}-\mathrm{H})$ aromatic stretch(phenyl), $v(\mathrm{C}-\mathrm{H})$ aromatic stretch(Furanyl), $v(\mathrm{C}-\mathrm{H})$ aliphatic stretching, $v(\mathrm{C}=\mathrm{O})$ hydrazine, $v(\mathrm{C}=\mathrm{N})$ azomethine, $v(\mathrm{C}-\mathrm{C})$ aromatic ring, $\mathrm{v}(\mathrm{C}-\mathrm{C})$ aromatic ring, $v(\mathrm{C}-\mathrm{C})$ aromatic ring, $v(\mathrm{C}-\mathrm{N})$ stretch vibrations respectively.

ii. ${ }^{1} \mathbf{H}-\mathrm{NMR}$ spectrum of $\mathbf{A F B H}$ : (CDCl3+DMSO-d6) showed signals at $2.33(3 \mathrm{H}, \mathrm{s}), 6.61-7.58(3 \mathrm{H}, \mathrm{m})$ and $7.61-8.6(5 \mathrm{H}, \mathrm{m})$ and 
$10.70(1 \mathrm{H}, \mathrm{s})$ due to $\mathrm{CH}_{3}$, furan and Benzene protons, - $\mathrm{NH}$ (imino) groups of hydrazone respectively.

iii. Mass spectrum of AFBH: shows molecular ion peak is observed at $\mathrm{m} / \mathrm{z}$ value of 251 . This corresponds to molecular ion peak. It is $[\mathrm{M}+\mathrm{Na}]$ peak and most intense peak. Another peak is observed at $\mathrm{m} / \mathrm{z}$ value of 237. It corresponds to $\mathrm{M}-\mathrm{CH}_{3}\left(\mathrm{M}\right.$ minus $\left.\mathrm{CH}_{3}\right)$.

iv. The pKa values of AFBH: The pKa values of AFBH were determined by recording the UV-Visible spectra of micro molar $\left(4 \times 10^{-6}\right.$ $\mathrm{M}$ ) solution of the reagent at various $\mathrm{pH}$ values and by taking the arithmetic means of the values obtained from the measurements at different wavelengths determined spectrophotometrically using Phillip and Merritt method. The values of deprotonation of AFBH are $5.93(\mathrm{pK} 1)$ and $8.66(\mathrm{pK} 2)$ corresponding to the formation of enol form and conjugated mono anion form respectively.

$v$. The compound shows strong absorption band in UV region due to $\pi-\pi^{*}$ transition. In alkaline medium ( $\mathrm{pH} 8.0-10.0$ ), this band is shifted towards higher wavelength due to formation of conjugated negative anion. The chromogenic characteristics of AFBH are given in Table 1.

Table I Chromogenic characteristics of AFBH

\begin{tabular}{|c|c|c|c|c|}
\hline Metal ion & $\lambda_{\max }$ & $\varepsilon$ I. $\mathrm{mol}^{-1} \mathrm{~cm}^{-1}$ & $\mathrm{pH}$ range & Colour of the complex \\
\hline $\mathrm{Cu}(I I)$ & 360 & $2.06 \times 10^{4}$ & 6.5 & Pale greenish yellow \\
\hline $\mathrm{Hg}(\mathrm{II})$ & 363 & $2.5 \times 10^{3}$ & 6.5 & Greenish yellow \\
\hline $\mathrm{Fe}(\mathrm{III})$ & 360 & $1.4 \times 10^{3}$ & 6.0 & Deep yellow with red tingle \\
\hline $\mathrm{Cr}(\mathrm{III})$ & 363 & $3.2 \times 10^{3}$ & 6.0 & Deep yellow \\
\hline $\mathrm{Pb}(\mathrm{II})$ & 380 & $5 \times 10^{4}$ & 6.0 & Yellowish \\
\hline $\mathrm{Ni}(I I)$ & 380 & $3.9 \times 10^{3}$ & 6.0 & Greenish yellow \\
\hline Cd(II) & 415 & $3.9 \times 10^{3}$ & 6.0 & Greenish yellow \\
\hline
\end{tabular}

$0.2 \mathrm{M}$ sodium acetate $-0.2 \mathrm{M}$ acetic acid $(\mathrm{pH} 6.5)$ was used in the present study. The standard $\mathrm{Cu}$ (II), solution $\left(1 \times 10^{-2} \mathrm{M}\right)$ was prepared by using analytical reagent grade $\mathrm{Cu}\left(\mathrm{CH}_{3} \mathrm{COO}\right)_{2} \mathrm{H}_{2} \mathrm{O}$. The stock solution of copper (II) was standardized using titrimetric and gravimetric methods respectively. Shimadzu 160A UV visible spectrophotometer equipped with $1.0 \mathrm{~cm}$ quartz cells and Elico Model LI-120 $\mathrm{pH}$ meter were used in present study.

The reactions of some important metal ions were tested at different $\mathrm{pH}$ values. The samples were prepared in $25-\mathrm{ml}$ volumetric flask by mixing $10 \mathrm{ml}$ buffer, $1 \mathrm{ml}$ of metal ion and $1.5 \mathrm{ml}$ of $0.001 \mathrm{M} \mathrm{AFBH}$ solution. The reaction mixture was diluted to mark with distilled water. The absorbance was measured in $350-600 \mathrm{~nm}$ range against the reagent blank.

An aliquot of metal ion in the Beer's law validity range 1.02$10.2 \mu \mathrm{g} / \mathrm{ml}$ of $\mathrm{Cu}(\mathrm{II}), 10 \mathrm{ml}$ of buffer solution ( $\mathrm{pH} 6.5$ ) $2.5 \mathrm{ml}$ of DMF and $1.5 \mathrm{ml}$ of $1 \times 10^{-2} \mathrm{M}$ AFBH solution were taken in $25-\mathrm{ml}$ standard flask and diluted to the mark with distilled water. The absorbance of the coloured solution as measured at corresponding wavelength (360) against reagent blank. Calibration graph were prepared. The measured absorbance values were used to compute the amount of copper present in the unknown solution.

\section{Results and discussion}

The reagent 2-acetylfuran benzoylhydrazone is easily prepared under reflux conditions. A $0.001 \mathrm{M}$ solution of AFBH is stable for more than 12 hours. In buffer medium ( $\mathrm{pH}$ 6.5), the ligand presumably exists in enolic form and coordinates the divalent metal ion as mono anion.

\section{Determination of copper (II)}

Copper (II) reacts with AFBH in acidic $\mathrm{pH}(6.5)$ to give coloured complexes. The colour reaction is instantaneous even at room temperature. The order of addition of reagent, metal ion, buffer, $2.5 \mathrm{ml}$ of DMF. A 10-fold molar excess of the reagent is adequate for full colour development. Addition of excess of reagent has no adverse effect on the absorbance of the complexes.

The system obeys Beer's law in the concentration range 1.02$10.2 \mu \mathrm{g} / \mathrm{ml}$ of copper. The molar absorptivity and Sandell's sensitivity of the methods for $\mathrm{Cu}(\mathrm{II})$ is found to be $2.06 \times 10^{4} \mathrm{Lmol}^{-1} \mathrm{~cm}^{-1}$ and $3.1 \times 10^{3} \mu \mathrm{g} / \mathrm{cm}^{2}$ respectively. The specific absorptivity of the system $0.3245 \mathrm{ml} / \mathrm{g}^{-1} \mathrm{~cm}^{-1}$. The relative standard deviation for ten replicate analysis of $\mathrm{Cu}$ (II) is $0.24 \%$. Job's ${ }^{6}$ and Molar ratio methods gave the composition of $\mathrm{Cu}$ (II) complex as 1: 1, (M: L). The stability constants of is calculated by Job's method is found to be $5.97 \times 10^{6}$.

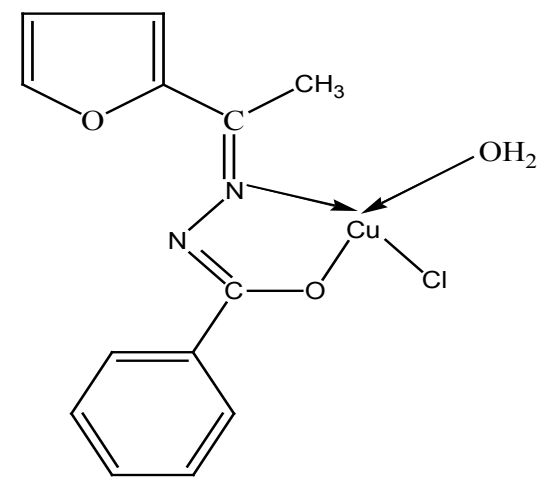

Figure 2 Structure of $\mathrm{Cu}$ (II) complex of $\mathrm{AFBH}[\mathrm{M}: \mathrm{L}=\mathrm{I}: \mathrm{I}]$

\section{Applications}

\section{Determination of copper in green leafy vegetable, soil, biological and samples}

The present methods is applied for the determination of $\mathrm{Cu}$ (II) in green leafy vegetable, soil and biological samples and results were given (Tables $2 \& 3$ ).

Vegetable samples: ${ }^{7-9}$ Dry ashing method was used in the analysis of organic samples. A $10 \mathrm{~g}$ of dried leafy vegetable sample was taken 
in a silica dish. The sample was heated over a low burner until the material chars. The charred mass was moistened with $1: 1 \mathrm{HNO}_{3}$. Occasionally a $20 \%$ solution of magnesium nitrate was used for this purpose, particularly if the ash content is very low. Again evaporated to dryness, and transferred to a muffle furnace. The temperature to about $500^{\circ} \mathrm{C}$ was reached in the course of about 3 hours. Heating was continued until the ash becomes white. The dish was cooled and the ash was dissolved in a $5 \mathrm{ml}$ portion of $1: 1 \mathrm{HCl}$. Distilled water was added amounting to about twice the volume of acid added. The solution was filtered to remove any insoluble residue and washed with 1: $4 \mathrm{HCl}$. The solution was diluted to $50 \mathrm{ml}$ in a standard flask. Aliquots of this sample were taken for the determination of copper by following procedure given above. The results were given in Table 2 .

Table 2 Determination of copper in some leafy vegetable samples

\section{Name of the Samples ${ }^{b} \quad$ Amount of copper found $(\mu g / l$ in dried leaves)}

\section{AFBH method Dithizone method}

\begin{tabular}{lcc}
\hline $\begin{array}{l}\text { Thotakura (Amaranthus } \\
\text { gangeticus) }\end{array}$ & 0.261 & 0.265 \\
$\begin{array}{l}\text { Chukkaku (Irumex } \\
\text { vesicarius) }\end{array}$ & 0.261 & 0.236 \\
$\begin{array}{l}\text { Tutikura (Ipomoea reptuns) } \\
\begin{array}{l}\text { Cauliflower Green (Brassica } \\
\text { deraceavar botntis) }\end{array}\end{array}$ & 0.305 & 0.290 \\
\hline
\end{tabular}

Medicinal leaves

Vepaku (Azadirachta indica) $\quad 0.29$

0.275

Gaddi Chamanti (Tridax procombens $L$ )

0.123

0.121

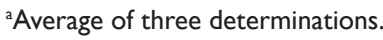

bSamples collected from Itikala palli, near SK University, Anantapur

Biological samples: ${ }^{10,11} \mathrm{~A} 2-5 \mathrm{~g}$ of dried fish and sheep liver samples were taken in a $250 \mathrm{ml}$ beaker. A $6 \mathrm{ml}$ of concentrated nitric acid was added and gently heated for half-an-hour. After the disappearance of the froth, $6 \mathrm{ml}$ of 1:1 nitric acid and perchloric acid were added. The contents were digested for one hour and repeatedly treated with $6 \mathrm{ml}$ portions of nitric acid and perchloric acid mixture until the solution becomes colourless. The acid solution was evaporated to dryness and the resulting white residue was dissolved in minimum volume of $1 \mathrm{M}$ nitric acid and made up to the volume in a $50 \mathrm{ml}$ volumetric flask. Aliquots of this solution were taken for analysis by following recommended procedure given above. The results were given in Table 3.
Table 3 Analysis of liver samples

\begin{tabular}{lll}
\hline Liver Sample & \multicolumn{2}{l}{$\begin{array}{l}\text { Amount of copper } \\
\text { liver) }\end{array}$} \\
\cline { 2 - 3 } & AFBH method $(\mu \mathrm{g} / \mathrm{ml}$ in dried & Dithizone method \\
\hline Fish liver & 1.289 & $\mathrm{I} .203$ \\
Sheep liver & 1.258 & 1.280 \\
\hline Soil Samples & & \\
\hline Urban soil & 8.45 & 8.98 \\
Agricultural soil & 7.45 & $7.4 \mathrm{I}$ \\
Road side soil & 9.68 & 9.62 \\
\hline
\end{tabular}

\begin{tabular}{lll}
\multicolumn{2}{l}{ Range of copper as per CWI and WWI sites ${ }^{10}$} \\
\hline & Clean water & Waste water \\
\hline Water & 0.003 & 0.056 \\
Soil & 8.39 & 21.33 \\
Caulioflower & 0.391 & 0.597 \\
Amaranthus & 0.221 & 0.344
\end{tabular}

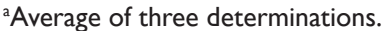

bSamples collected from Parnapalli Project, Anantapur

'Anantapur Urban and town area.

\section{Recommended procedure}

A known aliquot of the sample solution was taken in a $25 \mathrm{ml}$ standard flask containing buffer solution of $\mathrm{pH} 6.5$, and reagent [AFBH; $1.5 \mathrm{ml} 1 \times 10^{-2} \mathrm{M}$; Stock solutions] solution and made up to the mark with distilled water. Absorbance of the solution was measured at $\lambda_{\max }$ against the reagent blank. The absorbance values were referred to the predetermined calibration plot to compute the amount of copper.

\section{a) Soils samples ${ }^{10-12}$}

A $2 \mathrm{~g}$ weight of soil, $5-7 \mathrm{ml}$ of concentrated $\mathrm{H}_{2} \mathrm{SO}_{4}$ and an excess of $\mathrm{KMnO}_{4}$ are mixed in a conical flask equipped with a reflux condenser. The crystals of $\mathrm{KMnO}_{4}$ are added slowly in small portions, while stirring. It is heated until vapours of $\mathrm{SO}_{3}$ are evolved. After cooling down, $10 \mathrm{ml}$ of distilled water are added. The excess of $\mathrm{KMnO}_{4}$ and manganese oxides are eliminated by adding $\mathrm{H}_{2} \mathrm{O}_{2}$. Iron is isolated by precipitation as hydroxide. After filtration, the solution is transferred into $25 \mathrm{ml}$ standard flask and the volume is brought to the mark with distilled water. Aliquots of this solution were taken for analysis by following procedure given above. The results were given in Table 3 .

\section{Conclusion}

The present was applied to various green leafy vegetables, soil and biological samples and compared with standard Dithizone method. ${ }^{13}$ The results were quite encouraging and brings awareness among the public regarding the importance of copper and its adverse effects if present in excess. ${ }^{14}$ 


\section{Acknowledgements}

The author thank to Dr. BV Subba Reddy and K Venkatesulu I I C T Hyderabad for providing IR, NMR, Mass spectra.

\section{Conflict of interest}

The author declares no conflict of interest.

\section{References}

1. Sarkar M, Das M. Annal set-The Environmental Protection. 2005;7:15

2. Horwarth DJ. The Substances and Health-A hand book. USA: Marce Dekker; 1996.

3. Bendix GH, Grabenstetter D. Dithizone Method for Rapid Determination of Copper. Ind Eng Chem Anal Ed. 1943;15(10):649-652.

4. Subramanyam SL, Kumar JR, Reddy KJ, et al. Development of an extractive spectrophotometric method for the determination of copper (II) in leafy vegetable and pharmaceutical samples using pyridoxal-4-phenyl-3-thiosemicarbazone (PPT). J Agric Food Chem. 2005;53(14):5492-5498.

5. Saleem Basha V. PhD thesis. India: SK University; 2008.
6. Job P. Formation and Stability of Inorganic Complexes in Solution. Ann Chim (Paris). 1928;9:113-203.

7. Vogel AI. A Text Book of Quantitative Inorganic Analysis. 3rd ed. UK ELBS and Longman; 1975. 325 p.

8. Snell FD, Snell CT. Colorimetric methods of analysis. 3rd ed. 1949 11:92.

9. Anita S, Rajesh KS, Madhoolika A, et al. Risk assessment of heavy metal toxicity through contaminated vegetables from waste water irrigated area of Varanasi, India. Tropical Ecology. 2010;51(2S):375-387.

10. Kamburova M. Spectrophotometric determination of mercury in soils with triphenyltetrazolium chloride. Talanta. 1993;40(5):719-723.

11. Hussain Reddy K. PhD thesis. India: Sri Krishnadevaraya University, New Age International P Ltd; 1983.

12. Marczenko Z. Spectrophotometric determination of elements. New York: Wiley; 1976. p. 241,351,602.

13. Brajesh Kumar, Harbhajan Singh, Mohan Katyal, et al. Acta III. 1991:79-87.

14. Saleem Basha V, Vidyasagar Babu S, Hussain Reddy K. Journal of Pharmacy and Chemistry. 2013;7(1):30-35 